\title{
The Sandhill Crane Management Project at Last Mountain Lake
}

by R. H. Mackay, Canadian Wildlife Service, Edmonton

Reprinted from the Nokomis Times, August 30, 1961

Following a preliminary crane investigation in the vicinity of Last Mountain Lake in 1960, the Canadian Wildlife Service of the Department of Northern Affairs and National Resources has intensified its efforts this year. A crew of nine men based at Nokomis under the direction of Doug Stephen, Canadian Wildlife Service biologist, Saskatoon, has been keeping close watch on crane movements throughout the 325 square mile study area.

Different types of automatic exploders for scaring birds have been tested by the Service over the past several years. Each type was found to have mechanical faults which precluded recommendation for use by individual farmers. During the past winter an electrically-controlled exploder was developed by the $\mathrm{Na}$ tional Research Council at the request of the Wildlife Service. This exploder has been under test this season and, although rather unwieldy in its present form, produces the loud bang required for scaring with minimum attention in the field.

Crane movements have been followed closely and exploders set upwith permission from the farmerwhere cranes were seen damaging crops. It is of interest to note here that one farmer refused permission to install an exploder because he thought the cranes were eating more pesky grasshoppers than grain! In any event the exploders have proved most effective in protecting crops this season. It has only been necessary to use them in thirty fields.

This brings up the point that has been raised-where do the cranes go to feed when chased from unharvested crops? Under early harvesting conditions such as occurred this year and last, there is no great problem as the birds can find plenty to eat in early-harvested stubble fields. However, in years when the harvest is delayed by adverse weather conditions, stubble fields may not be avail- able for hungry birds. This problem has not been overlooked and initial steps have been taken to solve it. The Saskatchewan Game Branch has grown lure crops for cranes on their Game Preserve for the past several years. Granted the grain so grown would not satisfy the appetites of all the cranes in the area, but this year the Canadian Wildlife Service has cooperated with the Provincial Game Branch to double the lure crop acreage. It is realized that this acreage, too, would probably be inadequate in 'bad years but a start has been made. Further study will be necessary to determine how much more lure crop is required to meet the situation realistically.

What of the future? The most important problem to be solved is the manufacture of a compact exploder of the type devised for the Wildlife Service this year. This machine must be available for acquisition and use by the individual farmer at a price

(Continued on page 164)

\section{RALPH STUECK WINS CONSERVATION AWARD}

On October 17, 1961, the Julian Crandall Conservation Trophy was awarded to Burt S. Moore of Andova, N.B., and Ralph Stueck of Abernethy. The trophy is awarded annually by the Canadian Tourist Association to the Canadian citizen who "through word, thought, effort and deed, is considered to have contributed most to conservation of the renewable resources of forest, field and stream in Canada."

We rejoice in this honour that has come to our well-known naturalist, known to his friends as "Hiawatha" because he understands and speaks the language of wild creatures. For his work in Abernethy where he has both a private museum and wildlife sanctuary, and for his contacts throughout the province where he travels with his wildlife films, Ralph richly deserves this honour. 